\title{
The Influence of Perceptions Towards Preference Communities on Islamic Banks in Polewali Mandar District, West Sulawesi
}

\author{
Sri Astuty Ratnasari Manggu', Dahlia Dahlia ${ }^{2}$ \\ \{ sriastutyrm@unsulbar.ac.id ${ }^{1}$,dahlia@unsulbar.ac.id ${ }^{2}$ \} \\ ${ }^{1,2}$ Department of Accounting, Economy Faculty, Universitas Sulawesi Barat, Indonesia
}

\begin{abstract}
This research aims to know the influence of perceptions over societal preference towards Islamic banking at bank syariah in Polewali Mandar District, West Sulawesi. Method of data collection is done with the withdrawal of samples from a population with a cluster system: i.e. a conventional bank clients, Islamic bank clients, Islamic and conventional banks clients, and the general public. The technique of collecting data through questionnaires distribution, while data analysis is done using a simple linear regression analysis. The results showed that the public perception towards Islamic banking influential positively and significantly to community preference in the Islamic bank. From the perception, in General most of the people know the existence of Islamic banks. But perceptions related to the principles of Islamic banking with different conventional bank is still not much well understood by most people. Meanwhile, the preferences of the community towards Islamic banking, the majority of the community based on the results of the questionnaire have not fully put its options on Islamic banking.
\end{abstract}

Keywords: Perception, Preferences Communities, Islamic Banks.

\section{Introduction}

The demand for Shariah-compliant products provided by financial institutions that run its activities in accordance with Sharia principles become a necessity which needs to be responded to complaints by Islamic banking. According to Islamic banking statistics issued by Bank Indonesia shows that at this time there have been 6 Sharia and 25 public bank syariah business unit owned by commercial banks, as well as conventional bank financing 138 Islamic people in Indonesia [1]. The potential for the development of Islamic banking is big enough given that most people in Muslim Indonesia.

But on the other hand, the potential and the role of Islamic banking has not been followed by an increase in the market share of the Islamic banking compared with conventional banks. According to the financial services authority, market share Islamic banks against new national banking market total reached $4.87 \%$ at the end of the year 2016 or still below the target of at least 5\% [2]. Lack of interest in the community towards Sharia banking is caused by many factors. One factor is the lack of knowledge and understanding as well as the general public perception is still incorrect or inappropriately towards Islamic banking. Islamic banks are financial institutions that provide financing and real business services-other services in payment traffic and money circulation whose operations are adapted to the principles of 
Islamic jurisprudence [3]. Islamic banks with conventional banks have some differences between them:

Table 1. The difference of Islamic banks with a Bank Convensional

\begin{tabular}{|c|c|c|}
\hline The Different Types & Islamic Bank & $\begin{array}{c}\text { Conventiona } \\
\text { Banks }\end{array}$ \\
\hline Legal basis & $\begin{array}{l}\text { Qur'an Sunnah \& } \\
+ \text { positive law for } \\
\text { results }\end{array}$ & Positif law \\
\hline Operational basis & & Bank interest \\
\hline Product scheme & $\begin{array}{l}\text { Based on the } \\
\text { Syariah, such as } \\
\text { the mudharabah, } \\
\text { musyarakah, } \\
\text { wadiah, murabaha } \\
\text { etc. }\end{array}$ & Bank interest \\
\hline Treatment of Community Fund & $\begin{array}{l}\text { Community Fund } \\
\text { is a new } \\
\text { investment } \\
\text { deposit/get results } \\
\text { when cultivated } \\
\text { first }\end{array}$ & $\begin{array}{l}\text { Community } \\
\text { funding is the } \\
\text { deposits to be } \\
\text { paid interest } \\
\text { maturity }\end{array}$ \\
\hline Legal basis the sector distribution of funds & $\begin{array}{l}\text { Al Qur`an \& as } \\
\text { Sunnah+Positive } \\
\text { law }\end{array}$ & $\begin{array}{l}\text { Positive law } \\
\text { not } \\
\text { halal/haram }\end{array}$ \\
\hline Organization & $\begin{array}{l}\text { There are Shariah } \\
\text { Supervisory } \\
\text { Board }\end{array}$ & $\begin{array}{l}\text { There are not } \\
\text { Syariah } \\
\text { Supervisory } \\
\text { Board }\end{array}$ \\
\hline
\end{tabular}

According to Webster, as quoted by Sutisna [4], states the perception is the process of how a stimulus-stimulus affecting response-the response was selected and interpreted. The stimulus is any form of physical or verbal communication that can affect an individual's response. One of the important stimulus that can affect consumer behavior is the environment (social and cultural). because of the perception each person against an object will be differentbada, therefore subjective perceptions have. The perception of a consumer going to various stimulus received in influence by its own characteristics. According to Nevita and Arifin in the states that in everyday life perceptions are more identified as views, which means how a person views an object or event at a given moment. The results of these observations will be processed consciously so that the individual can then give meaning to the object being observed [5].

Meanwhile, in the Complete Dictionary, mentioned that preference is right (to) take precedence and precedence, priority, options trend or joy in using or utilizing a goods or services [6]. Preference is the tendency of a person in choosing a product based on the desires, interests, and tastes. Where in this case a consumer expected to distinguish any product that will be encountered, as well as making a list of preference (rank preference) of all such products. Consumer preferences are subjective, where the preference among consumers to 
each other are not the same. This inequality is caused by the difference in interest due to many factors.

From the results of research conducted by Lailatus Sembrada [7] about perceptions, behaviors and preferences of society against Bank Muamalat Tulungagung, Tulungagung public perception show that against Bank Muamalat Indonesia KCP Tulungagung It is good but on the other hand the Community preference Tulungagung against Bank Muamalat Indonesia KCP Tulungagung is still low. Based on some research above shows that the understanding of the structure and the public perception that awakens all this time against banks accounting for of course it is not easy to be directed toward banking which is based on Islamic Sharia, particularly related public perception that still wrong about Islamic banking and leads to the Community preference still low to Islamic banks. Currently in the Regency Polewali Mandar Polewali town, especially in the Wonomulyo and have stood 4 Islamic banks, namely Bank Syariah Mandiri (BSM), Bank Muamalat branches of Polewali, Bank Muamalat Branches Wonomulyo, and BNI Syariah KCP Micro Wonomulyo. The development of Islamic banks in the Polewali Regency is still quite low.Based on the description that is displayed in the background above, then that becomes a problem formulation in this research is: What are the perceptions of Islamic banking influence on Community preference on Islamic banks in Polewali Mandar Regency? The purpose of this research is: To know the influence of perceptions towards Community preference over Islamic banking in Polewali Mandar Regency.

\section{Research Methods}

This research was conducted to know the influence of perceptions over societal preference towards Islamic banking at bank syariah in Polewali Mandar District, West Sulawesi. This research uses a quantitative approach.The data in this study obtained by way of disseminating a questionnaire to 125 people respondents in the Polewali Regency, especially in district of Wonomulyo and the town of Polewali.The population of this study includes people in two cities in the Polewali Mandar Regency, with the criteria that in each of these regions operate both types of banks (conventional banks and Islamic banks), namely: Polewali City and Wonomulyo City. The researcher determined the number of samples taken was 125 respondents. The research sample will be divided into four clusters: namely conventional bank customers ( 25 people), Islamic bank customers (25 people), Islamic and conventional bank customers (25 people), and the general public (50 people).This study analyzes data using quantitative analysis. Quantitative methods are needed to answer the problem statement about the influence of perceptions of Islamic banking on people's preferences on Islamic banks in Polewali Mandar Regency. In quantitative methods, this study uses Simple Linear Regression Analysis between perceptions (independent variables) and preferences. (dependent variable).

\section{Results and Discussion \\ 3.1. Data Analysis}

The data in this study obtained by way of disseminating a questionnaire to 125 people respondents in the Polewali Regency, especially in district of Wonomulyo and the town of Polewali. As for the rate of return the following questionnaire: 
Table 2. Rate of Return Questionnaire.

\begin{tabular}{|c|c|c|c|c|}
\hline No & Respondent & $\begin{array}{l}\text { Questionnaire } \\
\text { disseminated }\end{array}$ & $\begin{array}{l}\text { Questionnair } \\
\text { e returned }\end{array}$ & $\begin{array}{l}\text { Questionnai } \\
\text { re Not } \\
\text { returned }\end{array}$ \\
\hline 1 & Islamic Bank clients & 25 & 25 & 0 \\
\hline 2 & $\begin{array}{l}\text { Conventional Bank } \\
\text { clients }\end{array}$ & 25 & 20 & 5 \\
\hline 3 & $\begin{array}{l}\text { Islamic \& Conventional } \\
\text { Bank clients }\end{array}$ & 25 & 21 & 4 \\
\hline 4 & $\begin{array}{l}\text { General public } \\
\text { Total }\end{array}$ & $\begin{array}{l}50 \\
\mathbf{1 2 5}\end{array}$ & $\begin{array}{c}50 \\
116\end{array}$ & $\begin{array}{l}0 \\
9\end{array}$ \\
\hline
\end{tabular}

Source: Data Processed, 2017

The amount of a detailed questionnaire that was distributed was 125 , a questionnaire returned and can be processed 116. As for the questionnaire not returned because there are some communities that kuisionernya when prompted, say the missing and damaged. Rate of return questionnaire was $92 \%$. As for the characteristics of respondents as follows:

153 people-sex male or $46 \%$ and 63 women, or $54 \%$.

$297 \%$ Muslim and the rest $3 \%$ Christians.

3 the age of respondents was the most dominant are between the ages of 21-30 years as many as 43 people or $37 \%$ between the ages of 31-40 years as many as 40 people or $24 \%$, then followed the age of $41-50$ as many as 26 people or $22 \%$ and aged over the last 51 years of as much as 7 people or $6 \%$.

4 the last respondent's education level is dominated by High School/SMK/Equal as many as 53 people or $46 \%$ of Undergraduate education followed by as many as 49 people or $42 \%$ and Education Diploma as many as 10 people or $9 \%$ as well as the education of Master 4 people or $4 \%$.

5 the work undertaken by the respondent was dominated by Civil Servants that as many as 40 people or as many as $34 \%$ then followed by respondents who work as entrepreneurs/self employed as many as 31 people or $27 \%$, and respondents who work in other bidnag are not mentioned in the questionnaire as many as 23 people or $20 \%$, then as private employees by as much as $13 \%$ or 11 people as well as housewives each of as many as 10 people or $8 \%$.

\subsection{Descriptive Variable Analysis Research}

\section{Responses of respondents Against the variable X (Perception)}

Statement $1 \& 2$ research questionnaire submitted to the respondents related knowledge about the basis of the existence of Islamic banks i.e. existence of the MUI bank interest expressed about haraam because of the riba and an understanding of the system of interest that run on conventional categories include bank usury so contrary to Islamic jurisprudence. As for the result obtained that amounted to $41 \%$ of the respondents answered neutral, $28 \%$ answered Agree, $16 \%$ Disagreeing and the rest were answered respectively $12 \%$ replied strongly agree and $3 \%$ replied strongly disagree. And for statements 2, amounting to $39 \%$ of the respondents answering each neutral, 29\% of respondents answered agree, and 19\% answered don't agree, while $12 \%$ replied strongly agree and $1 \%$ replied strongly disagree. It showed most respondents indicate the nature of the neutral/undecided related fundamental understanding of 
the associated existence of Islamic banks that run the Sharia principle i.e. not allowed system interest in Islam due to including the category of usury.

Next statement $3 \& 4$ related public perception about Islamic banks as a bank that runs its system according to principles of Islamic jurisprudence and the principle for the results which applied Islamic bank that is more equitable than the system of interest. For statement 3 of $48 \%$ respondents answered agree, $26 \%$ Neutral answer, answered strongly agree 25\%, and $1 \%$ replied strongly disagree. And for statement 4, $47 \%$ of respondents replied, $28 \%$ answered Agree strongly agree, $22 \%$ responded neutral, $3 \%$ answered don't agree and sisaya $1 \%$ replied strongly disagree. Based on the composition of the answer can be known that most of the respondents agree to the existence of Islamic banks as banks that run the sharia principles with systems for different results with interest system run by the bank conventional. But there is still a large enough respondents who is also neutral or undecided

Statement $5 \& 6$ related statements that explain some of the wrong paradigm that is currently still growing, i.e. Islamic bank is not a bank specifically for Muslims because Islamic principles which are universal and thought that basically principles of Islamic banking system or just the same as conventional banks is not true. For statement 5 most respondents answered Agree i.e. amounted to $53 \%$, followed by the neutral answer of $22 \%, 21 \%$ of respondents answered strongly agree, and $3 \%$ of respondents replied did not agree and the remaining $1 \%$ replied strongly disagree. Statement 6, 36\% of respondents answered Agree, followed by Neutral answer amounted to $32 \%$, then $19 \%$ respondents answer strongly agree $9 \%$ answered don't agree and the last $6 \%$ replied strongly disagree. The results show that respondents ' answers to the 5 statements respondents agreed that Islamic banking is not intended only for Muslims only. But on the other hand for a statement 6 , yet the overall respondents agree that Islamic banks different from conventional banks in running its business principles it is visible from most of these answers have yet to agree and still large enough neutral answer/ hesitation.

\section{Response of respondents Against the variable $Y$ (preferences)}

Based on a detailed questionnaire submitted to the respondents, the statement 1, 2 and 3 of the election-related community towards Islamic banking because of his understanding of the differences of the riba and the system for the results as well as obedience as Muslims (for which a variety of Islam especially) against the sharee'ah of Islam. In statement 1 respondent given the statement "I want or choose to become Islamic bank because my understanding of usury", all the while statement 2: "I liked the system for results on Islamic banks compared with the system interest on Public/Bank Conventional Banks. " While that statement 3 "I chose my obedience due to the Islamic Bank on Shari'a religious". For statement 1 of $43 \%$ of the respondents answered neutral, $34 \%$ answered agree, $11 \%$ answered strongly agree and the remaining $10 \%$ answered don't agree as well as $2 \%$ replied strongly disagree. And for statements 2 , amounting to $40 \%$ of the respondents answered agree, $36 \%$ of respondents answered strongly agree neutral, by $17 \%$, while $5 \%$ answered don't agree as well as $2 \%$ replied strongly disagree. Meanwhile, for statements 3 most respondents i.e. amounted to $47 \%$ responded neutral, $34 \%$ answered agree, $11 \%$ answered strongly agree, and $6 \%$ answered don't agree, as well as $2 \%$ replied strongly disagree. It showed most respondents indicate a neutral stance or election-related keragu-raguannya or desire to opt into the customer's bank due to Sharia. The reason of the understanding will be fundamental things that become the reason of the existence of a related system namely Islamic bank usury is not allowed in Islam, as well as adherence to religious rules, especially for Muslims. However for statements related to excess 
systems for results compared to the interest system so the principle of Islamic banking is the reason that many are chosen by the respondent.

Statement 4, 5 and 6 related Community preference towards Islamic banking is based on a product, service, and location of the fsasiltas. As for his statement as follows: statement of 4 "I think Sharia banking products better and more profitable", statement 5 "I chose Islamic banks because of the friendly service and amenities are complete", as well as a statement of My 6 " Choose the location due to the Islamic Bank with where I live ". As for the results of the responses of the respondents is as follows: for statement 4 , the majority of the respondents i.e. amounted to $46 \% 34 \%$, Neutral answer answer 13\% answered agree, strongly agree, $6 \%$ answered don't agree, and 1\% replied strongly disagree. For statement 5 most respondents answered Neutral i.e. amounted to $47 \%$, followed by an answer Agreed by $30 \%, 17 \%$ of the respondents answered strongly agree, and $3 \%$ of respondents replied did not agree and the remaining $2 \%$ replied strongly disagree. Statement $6,49 \%$ of respondents replied to neutral, followed by an answer Agreed by $25 \%$, then $13 \%$ of respondents answered strongly agree and $9 \%$ answered don't agree, and the remainder by $4 \%$ replied strongly disagree. Based on the composition of the answer can be known that most of the respondents choose the answer of neutral/undecided. This shows that from the side of preference towards Islamic banking, the respondents have not yet made the product, service, facilities and location are affordable as the basis of his election against Islamic banking.

\subsection{Hypothesis testing}

\section{Coefficient of Determination}

The coefficient of determination is the value that indicates the proportion of independent variable influences may explain the dependent variable. Based on the test results obtained by the determination coefficient values SPSS as follows:

Tabel 3. Coefficient of Determination

\begin{tabular}{lcccrr}
\hline Model & R & R Square & $\begin{array}{c}\text { Adjusted R } \\
\text { Square }\end{array}$ & $\begin{array}{c}\text { Std. Error of } \\
\text { the Estimate }\end{array}$ & $\begin{array}{l}\text { Durbin- } \\
\text { Watson }\end{array}$ \\
\hline 1 & $.505^{\mathrm{a}}$ & .255 & .249 & 3.549 & 1.755 \\
\hline a. Predictors: (Constant), the perception towards Is lamic Bank & \\
b. Dependent Variable: the preference of the society in Islamic Bank
\end{tabular}

From the above table it can be known that $\mathrm{R} 2$ of 0.255 , this value indicates that the independent variable (the perception towards Islamic banking) is only able to explain the dependent variable (the preference of the society in Islamic banks) amounted to $25.5 \%$ and the rest of $74.5 \%$ is explained by other variable which is not examined in this study. 


\section{Test T (Partial Influence)}

Partial test to find out whether there is influence between the public perception towards people's preferences in choosing Islamic banks. As for SPSS the test results obtained the following values:

Tabel 4. $T$ Test Result

\begin{tabular}{|c|c|c|c|c|c|c|}
\hline \multirow{3}{*}{ Model } & & \multirow{2}{*}{\multicolumn{2}{|c|}{ Unstandardized Coefficients }} & \multirow{3}{*}{$\begin{array}{l}\text { Standardized } \\
\text { Coefficients } \\
\text { Beta }\end{array}$} & \multirow{3}{*}{$\mathrm{t}$} & \multirow{3}{*}{ Sig. } \\
\hline & & & & & & \\
\hline & & $\mathrm{B}$ & Std. Error & & & \\
\hline \multirow{3}{*}{1} & (Constant) & 8.169 & 2.077 & & 3.933 & .000 \\
\hline & \multicolumn{6}{|l|}{ Persepsi } \\
\hline & \multicolumn{2}{|c|}{ Terhadap Bank .582 } & .093 & .505 & 6.248 & .000 \\
\hline
\end{tabular}

Based on table 4 above is obtained a value of significance for the variable $\mathrm{X}$ (public perception) of 0.000 . The provisions of decision making a hypothesis accepted or rejected based on the magnitude of the value of significance. If the significance is less than or equal to $0.05(0.05<)$,then the hypothesis is accepted and vice versa. The research results obtained significance value of $0.000(<0.05)$, it was concluded that the public perception on Islamic banks to Community preference over Islamic banks.

\subsection{Discussion of Research Results}

The development of Islamic banking when compared with conventional banking/General is still very far from either side of the number of customers, as well as from the side of gathering together and channelling funds. This also happens in the Sulawesi region West of Polewali Mandar Regency in particular. When viewed from a number of Islamic banks operating in Polewali Mandar Regency, currently there are only 3 Sharia banks namely 2 Islamic banks in the region of Wonomulyo and 1 syariah bank in Polewali region. Not only from the existence of the syariahnya bank, public perception has also become one of the things that the reason has not been growing Islamic banking in Polewali Mandar areas.

Based on the results of the analysis of the questionnaire disseminated to 116 respondents, showed that most respondents are generally already know about the existence of Islamic banking in Polewali Mandar region but from $89 \%$ of respondents who knowing about Islamic banking, only amounted to $41 \%$ who would later become the customer of Islamic banks. Most of the respondents thus is the customer of the conventional banking and some customer who also became the bank's conventional and syariah bank at once.

Still the lack of interest of society into Islamic banking clients can be seen from their perception towards Islamic banking itself. As a result of descriptive variables mentioned earlier that most of the answers of the respondents who answered undecided/neutral shows a lack of understanding of Islamic banking. As for the understanding of the definition of related fundamental things which is the reason the formation of Islamic banking as solutions to the needs of the community which then responded to banking industry banking system that is in accordance with the Shari'a The Islamic system of usury, namely flowers as currently applied in conventional banking. The public perception is mainly dominated by the lack of knowledge on them or the unfamiliarity of the riba has even been difatwakan by the MUI that 
categorizing system of usury is haram.Although in general the public perception mostly shows good results but the majority of the Community preference, based on the results of the questionnaire have not fully put its options on Islamic banking. This generally indicates that although the public has recognized but not necessarily be it encourage people to vote for Islamic banks.

\section{Conclusion}

The public perception towards Islamic banking influential positively and significantly to Community preference over Islamic banks. From the perception, in General most of the people know the existence of Islamic banks. But perceptions related to the principles of Islamic banking with different bank konvensioanl is still not much well understood by most people. Meanwhile, the preferences of the community towards Islamic banking, the majority of the community based on the results of the questionnaire have not fully put its options on Islamic banking.

\section{References}

[1] www.bi.go.id

[2] www.ojk.go.id

[3] Muhammad, Management of Islamic Banks. UPP AMP YKPN. Yogyakarta, 2002.

[4] Sutisna,Consumer Behavior and Marketing Communication. PT Remaja Rosdakarya. Bandung, 2001.

[5] Ary Permata Deny, Pevita and Arifin, Zainal, Behavior, Characteristics, Community Perceptions of Islamic Banks at Ex Kediri Residency. Nusantara of Research Journal. 2: $151,2015$.

[6] Meidar F.M, Complete Dictionary of Exclusive English - Indonesian. Eska Media. Jakarta, 2007.

[7] Prihasta, Lailatus Sembadra. Tulungagung Community's Perception, Behavior and Preference Against Bank Muamalat. Faculty of Islamic Economics and Business IAIN, Tulung Agung, 2015. 